\title{
AUSTRALIAN CARABID BEETLES II. SOME NEW PTEROSTICHINI
}

By P. J. Darlington, JR.

Museum of Comparative Zoology, Harvard University

This is the second of what I hope will be a continuing series of papers on Australian Carabidae. The first, with some information on sources of material and methods of work, appeared in Psyche, vol. 60, 1953, pp. 52-61. The present paper contains the descriptions of seven new Pterostichini of the Australian genera Leiradira, Setalis, Trichosternus, and Notonomus. Several of the new species either extend the known ranges of their genera or show unusual characters or variations. Except as otherwise stated, all the specimens here reported upon were collected by myself during the course of the Harvard Australian Expedition of 1931-1932.

\section{Genus Leiradira Cast.}

\section{Leiradira alternans $\mathrm{n}$. $\mathrm{sp}$.}

Of general form and appearance of previously known Leiradira (e.g. auricollis Cast.) but larger and narrower; color, including appendages, black or piceous (more rufous in recently emerged individuals) with outer antennal segments brown; rather shining, microsculpture faint, isodiametric on head, somewhat transverse on prothorax and elytra. Head normal for genus, .67 and .71 width prothorax in $\hat{o}$ o measured; antennae geniculate but with 1st segment shorter than usual in genus; frontal sulci deep, linear, somewhat curved and converging anteriorly, joined anteriorly by a variable but usually lightly impressed clypeal suture; surface impunctate. Prothorax appearing at least as long as wide but by measurement slightly wider than long; base about equal to apex; sides broadly arcuate, almost parallel $1 / 3$ from apex, strongly sinuate just before base; basal angles right; lateral margins very narrow, consisting of marginal bead only, with usual setae at base 
and about $1 / 3$ from apex; base subtruncate or slightly sinuate; apex subtruncate, with anterior angles very slightly advanced; sub-basal impressions in form of deep, somewhat elongate foveae, each connected with the margin posteriorly by a deep, curved impression; disc with median line light, transverse impressions obsolete, surface impunctate. Elytra $1 / 5$ or $1 / 4$ wider than prothorax, not or moderately narrowed anteriorly (variable), with sides subparalle] or slightly arcuate at middle, sinuate before apex, then rather narrowly and almost conjointly rounded; basal margin either entire and conspicuously lobed or interrupted at 1 st, 3rd, and 5th intervals (variation individual, not geographical), approximately rectangular and strongly elevated at humeri; striae rather deep, entire, impunctate, but finely granular at bottom; intervals alternately wide and narrow $(1,3,5$, and 7 wide), moderately convex on disc, more so laterally and apically; 3rd interval 2 , 3 , or 4 punctate, the punctures somewhat irregular in position as well as number; 8th and 9th intervals narrow and convex; fragments of a very narrow 10th (submarginal) interval posteriorly. Prosternal process not margined, declivity flat, without setae; metepisterna short; sides of sterna not much punctate, but sides of abdomen especially anteriorly extensively punctate, with the segments more or less impressed near sides. Fifth segment of tarsi without accessory setae below. Male with anterior tarsi a little dilated, first 3 segments biseriately squamulose; of with 1 , $q$ with 2 setigerous punctures each side last ventral segment. Length 14-16.5; width 4.1-5.0 mm.

Holotype of (M. C. Z. Type No. 29,016) and 3 paratypes from Malanda, Atherton Tableland, North Queensland, Nov. 7 and 8, 1950, collected by Dr. W. L. Brown in rotten logs in rain forest; and also the following additional paratypes: 3, Millaa Millaa, Atherton Tableland, about 2,500 ft. alt tude, April, 1932; and 1, Lake Barrine, Atherton Tableland, about 2,300 ft. altitude, April, 1932.

This, the first Leiradira to be recorded from North Queensland, is very distinct from all species previously assigned to the genus. The alternation in width of the elytral intervals is alone enough to distinguish it from, for example, L. auricollis Cast. and all other known speciez of the 
genus (keyed out and discussed by Tschitscherine in Horae Soc. Ent. Rossicae, Vol. 32, 1898, pp. 39-46), and there are many other specific differences. It is not so easy to say just how the new species is related to "Notonomus" opacistriatus Sl., which Sloane eventually decided was not a Notonomus (Proc. Linn. Soc. New South Wales, Vol. 38, 1913, p. 409 ), and which is from Cairns, below the Atherton Tableland. The two species are apparently related, but different. As compared with the description of opacistriatus, the present new species agrees in many significant details including alternation in width of the elytral intervals and opacity of the elytral striae, but Sloane's species is evidently a wider, less convex, somewhat differently shaped insect. This is shown by the measurements he gives ( 16 by $5.5 \mathrm{~mm}$. - a $16 \mathrm{~mm}$. specimen of the present new species would be less than $5 \mathrm{~mm}$. wide), by his statement that his species is oval and rather depressed while the present new species is subparallel and rather convex, and by his statement that in his species the prothoracic margins (as distinguished from the lateral channels) are narrow but wider toward the base while the present new species has no margins except the lateral channels, this being consistent with the new species being a narrower and more convex insect. I think that "Notonomus" opacistriatus Sl. will probably prove to be a link between Leiradira and more normally formed pterostichines, but I do not care to place it formally without seeing it.

\section{Genus Setalis Cast. \\ Setalis sloanei n. sp.}

Almost exactly like Setalis niger Cast. in form and appearance, but very much smaller; shining black, legs brownish piceous, antennae reddish brown; upper surface slightly silky but without distinct microsculpture. Head .62 and .59 width prothorax in of o measured, almost as in $S$. niger, swollen posteriorly, with small but even more abruptly prominent eyes; frontal impressions deep, irregular, somewhat converging, joined anteriorly by a sharply defined slightly emarginate clypeal suture; surface impunctate. Prothorax 1/4 wider than long, narrowed anteriorly, scarcely so posteriorly; base about $2 / 5$ wider than apex; sides 
broadly arcuate anteriorly, straight or even faintly sinuate and only slightly converging posteriorly; basal angles almost right but narrowly rounded; base broadly sinuate; apex subtruncate or very broadly emarginate, with anterior angles not advanced; lateral margins very narrow, with usual setae at base and about $1 / 4$ from apex; disc normally convex; sub-basal impressions short, deep, linear, irregular or subpunctate; a group of punctures (sometimes only 1 puncture) between sub-basal impression and lateral margin; disc otherwise impunctate, with median line light, transverse impressions vague; base not distinctly margined, apex margined at sides but not at middle. Elytra about $1 / 6$ wider than prothorax; sides subparallel, slightly sinuate before apex, then conjointly rounded; basal margin entire, bent forward and forming acute angles (more acute than in niger) at humeri; striae entire, deep, impunctate; intervals slightly convex on disc, more so laterally and apically; dorsal intervals equal, 3rd impunctate; 6th interval a little narrower especially at extremities; 7 th still narrower and abbreviated posteriorly (ending near apical $1 / 4$ ) ; 8th very narrow and a little more abbreviated (but not so short as in niger) ; 9th with usual ocellate setigerous punctures; a vague 10th interval present but not sharply separated from marginal trough. Prosternal process strongly margined (not so in niger), without setae; metepisterna short, they and sides of anterior ventral segments more or less punctate, but body below almost impunctate; last 3 ventral segments deeply transversely sulcate basally. Male with anterior tarsi moderately dilated, first 3 segments biseriately squamulose; last ventral seoment of both sexes with 1 conspicuous puncture (sometimes doubled) each side of middle. Length 6-7; width $2.4-2.8 \mathrm{~mm}$.

Holotype of (M. C. Z. Type No. 29,015) and 10 paratypes all from National Park, McPherson Range, South Queensland (on New South Wales border), 3,000-4,000 ft. altitude, March, 1932.

In appearance this new species is a diminutive of Setalis niger Cast., but the size difference is great (niger is 10-12 $\mathrm{mm}$. long), and there are some definite structural differences: the new species has more acute humeri, less abbreviated eighth elytral intervals, and a strongly margined pro- 
sternal process. (The M. C. Z. possesses a good series of niger from several localities in northern New South Wales and southern Queensland.) The new species very much resembles certain Setalimorphus, especially S. regularis Sl. (which we have), but differs in the unusual modification of the seventh and eighth elytral intervals.

Genus Trichosternus Chd.

Trichosternus relictus $n$. sp.

Rather elongate in genus, subparallel, normally convex; piceous black with purplish reflections especially on head, pronotum, and elytral margins (sometimes brassy on head and pronotum) ; legs piceous; antennae with 3 basal segments piceous, other segments pubescent and progressively paler brown; head and pronotum shining, with microsculpture fine and lightly impressed (nearly isodiametric on head, somewhat transverse on pronotum); elytra (except margins) duller, with microsculpture fine but deeply impressed, isodiametric; but marginal trough of elytra shining, with microsculpture faint; whole insect virtually impunctate above and below, except for punctures of fixed setae. Head large, .77 and .85 width prothorax in $s$ ? measured, but appearing wider; mandibles rather short; eyes small but convex, slightly more prominent than genae; genae barely longer than eyes, convex in profile; 2 setae above each eye; frontal impressions parallel, not deep, rather irregular; mentum deeply emarginate, with tooth rather broad, short, channeled; labium bisetose; paraglossae glabrous; inner lobe of maxilla strongly curved in at apex, with inner margin densely ciliate. Prothorax nearly $1 / 3$ (width/length 1.33 and 1.31 in 8 \& measured) wider than long, widest about $1 / 3$ from apex; base slightly narrower than apex; sides only moderately arcuate anteriorly, slightly arcuate or straight or at most faintly sinuate posteriorly; basal angles narrowly rounded, obtuse; base broadly and shallowly emarginate; apex scarcely emarginate, with anterior angles slightly advanced; lateral margins rather narrow anteriorly, a little wider posteriorly, each with a seta near (just before) base and at about apical 1/3; baso-lateral impressions irregularly rounded, each with whole bottom occupied by a low tubercle; disc normally 
convex, with usual middle line and transverse impressions; base and apex margined at sides but not at middle. Elytra subparallel, only slightly narrowed anteriorly, rather long (in genus), only about $1 / 5$ or less wider than prothorax (appearing scarcely wider) ; basal margin entire, strongly (almost rectangularly) angulate at humeri but not distinctly dentate; sides almost straight, then increasingly arcuate, without distinct subapical sinuations, to right or slightly obtuse sutural angles; striae well impressed, punctate; intervals all rather strongly and almost equally convex, 3rd with single setigerous puncture very near apex, 5th with 2 punctures, set respectively well forward (about as far from base as from suture) and well back (punctures somewhat variable in position and single punctures sometimes absent). Prosternal declivity and apex of mesosternum setose; last ventral segment 4 -setose (2 setae each side) in both sexes. Male with anterior tarsi normally dilated, first 3 segments biseriately squamulose. Length 23-28; width about 7.4-8.3 $\mathrm{mm}$.

Holotype of (M. C. Z. Type No. 29,010) and 19 paratypes all from near the town of Margaret River, southwestern division of Western Australia, October, 1931, taken under $\operatorname{logs}$ on the ground in eucalyptus woods.

This is the first species of the whole Trichosternus complex to be found in Western Australia. It is a very distinct species, and I am unwilling to assign it to any recognized subgenus of the genus, much less to say to what other species it is most closely related. Superficially it is something like T. (Castelnaudia) speciosus Sl., but is more parallel-sided, with sides of prothorax not or at most faintly sinuate, and with elytral intervals all about equally convex.

Trichosternus soror $n . \mathrm{sp}$.

Form average in genus, small, rather convex; piceous black, upper surface purplish, color brightest on head and pronotum; legs piceous; antennae with 3 basal segments reddish piceous, outer ones browner; head and pronotum shining, with microsculpture fine, light, about isodiametric on head, slightly transverse on pronotum; elytra duller but still somewhat shining especially on tops of subcostate intervals, with more deeply impressed, fine, isodiametric 
microsculpture; sides of elytra (8th intervals) dull, with almost granular microsculpture. Head 4/5 (.79 and .81) width prothorax but appearing wider; mandibles moderately long; eyes small but convex, scarcely more prominent than genae; genae slightly shorter than eyes, convex in profile; 2 setae over each eye; frontal impressions parallel, not deep, irregular; mentum tooth bifid. Prothorax subcordate, about $1 / 5$ or $1 / 4$ wider than long (width/length 1.20 and 1.27 ), widest about $1 / 3$ from apex; base a little (about $1 / 10$ ) narrower than apex; sides moderately arcuate anteriorly, then straight and converging posteriorly, then moderately sinuate before almost-right posterior angles; base scarcely emarginate at middle, slightly oblique at sides; apex very broadly and slightly emarginate, with anterior angles slightly advanced; lateral margins rather narrow anteriorly, very narrow posteriorly, each with a seta at basal angle and another about 1/3 from apex; baso-lateral impressions normaì, sub-linear, somewhat wrinkled but not distinctly punctate; disc normal; basal area longitudinally, irregularly striate; base and apex not distinctly margined except near sides. Elytra suboval, narrowed anteriorly, a little more convex than usual in genus, $1 / 4$ to $1 / 3$ wider than prothorax; basal margin entire, almost rectangularly angulate and subdentate at humeri; sides broadly rounded; subapical sinuations almost absent; sutural angles nearly right but slightly blunted; striae fine, defined mostly by slope of intervals, rather finely punctate; intervals 1 to 7 strongly convex, subcostate, almost equal in height except 7 th higher and costiform basally; 8th interval about same width but only slightly convex and very dull; 9th (submarginal) interval narrow and shining; each 3rd interval with 3 setigerous punctures spaced in posterior half (none anteriorly). Prosternal process and mesosternal declivity setose; sides of metasternum (not episterna) with a few coarse punctures but body below otherwise virtually impunctate. Male with front tarsi not dilated and with no sexual pubescence; last ventral segment of male with 1 strong setigerous puncture each side and several smaller ones in from margin near middle, of female with 2 setigerous punctures on one side and three on other. Length about 21 ; width about $6.7 \mathrm{~mm}$. 
Holotype $\delta$ (M. C. Z. Type No. 29,011) and 1 paratype both from Millaa Millaa,, Atherton Tableland, North Queensland, about 2,500 ft. altitude, April, 1932, in "scrub" (rain forest).

The unmodified front tarsi of the male set this species apart from most others of the genus. Otherwise the new species somewhat resembles T. (Castelnaudia) nitidicollis Cast. and its allies (of South Queensland etc.), but differs in having the discal elytral intervals ( 1 to 6 ) almost equally elevated instead of alternatelv so and it differs also in various minor characters. Unmodified male tarsi occur in T. subvirens Chd. and T. simplicipes Sl. (of South Queensland) but in these species the mentum tooth is rounded, not bifid as in the present new species, and there are many other specific differences. For these reasons I doubt if the new species is very closely related to any previously known one. This species is, of course, very small within its genus.

Genus Notonomus Chd.

The following three new species of Notonomus go with $N$. doddi Sl. and saepestriatus Sl. (both known to me only by description) to form a subgroup of the "kingi-group" of Sloane's second revision of the genus (Proc. Linn. Soc. New South Wales, Vol. 38, 1913, pp. 404-449, esp. pp. 437-440). The subgroup is apparently confined to North Queensland (known from the Atherton Tableland and Mt. Spurgeon) and is characterized by having the posterior-lateral setigerous puncture of the margin of the pronotum on the margin at the basal angle; the elytra fully and strongly striate, with the third interval not more than (but sometimes less than) 2-punctate and the fifth and seventh in.tervals impunctate, and the eighth interval (the tenth in the species with extra intervals) narrow and convex: the metepisterna short; the intercoxal declivity of the prosternum flat and without setae; the tarsi not striate above; the posterior tarsi with the first segment rather long (but not quite so long as the next two together), with the clawsegment glabrous below; and with secondary sexual characters normal, that is the male with one seta on each side of the last ventral segment and the female with two setae each side, and the male with the anterior tarsi moderately 
dilated and with the first three segments biseriately squamulose below and the female usually with these tarsi unmodified - but see under N. masculinus, below. The species of this subgroup differ remarkably among themselves in some other characters, as the following key shows. Incidentally, Mt. Spurgeon is probably the most northern locality at which any Notonomus has been found.

Key to the species of Notonomus of the doddi subgroup

1. Elytron with 9 normal intervals plus a narrow 10th submarginal one which does not reach base . . . 2

- Elytron with 11 intervals plus the narrow submarginal one (7th interval triplicate) . . . . . . 4

2. Head and pronotum shining; elytral intervals not catenulate . . . . . . . spurgeoni n. sp.

- Head and prothorax dull; elytral intervals catenulate

3. Pronotum transversely striolate; elytron with 3rd interval 2-punctate . . . . . . . . . doddi Sl.

- Pronotum longitudinally striolate; elytron with 3rd interval impunctate . . . . . . masculinus $\mathrm{n}$. sp.

4. Pronotum shining; elytral intervals not much catenulate (only 2nd interval crenulate on apical declivity) saepistriatus SI.

- Pronotum dull; elytral intervals more extensively subcatenulate . . . . . . triplicatus n. sp.

Notonomus spurgeoni n. sp.

With characters of doddi subgroup (above) ; a little more slender than usual but otherwise of about average form and convexity for genus; purple or purplish above, piceous below, with appendages piceous to brownish-piceous; rather shining; microsculpture fine and light (heavier on elytra), isodiametric in head and elytra, perhaps slightly transverse (but faint) on pronotum. Head normal for genus, .70 and .67 width prothorax in 8 o measured. Prothorax a little wider than long (width/length 1.12 and 1.20 in $\hat{o}$ o measured) but appearing as long as wide; base about $1 / 10$ wider than apex; sides broadly and rather weakly arcuate for most of length, then straight or faintly sinuate near base; 
posterior angles rather variable, slightly obtuse or right, more or less denticulate; base slightly sinuate; apex slightly and broadly emarginate, the anterior angles scarcely advanced beyond the line of the emargination, narrowly rounded; lateral margins very narrow, scarcely wider toward base; baso-lateral impressions normal, linear, impunctate, reaching base; middle line distinct, transverse impressions sub-obsolete; disc impunctate, with lightly impressed transverse wrinkles; basal and apical marginal lines widely interrupted at middle. Elytra subparallel, not or slightly narrowed anteriorly, not much wider than prothorax (1.13 and 1.17 as wide in measured $\hat{o}^{\circ}+$ ) ; basal margin entire; strongly (almost acutely) angulate and subdentate at humeri; striae deep, impunctate; intervals convex, not catenulate (except extreme lateral ones), 3rd 2punctate, the punctures near middle of length and behind apical 1/4. Length 13.5-18.0; width $4.0-5.3 \mathrm{~mm}$.

Holotype of (M. C. Z. Type No. 29,012) and 16 paratypes all from Mt. Spurgeon, North Queensland, 3,500-4,000 ft. altitude, July, 1932, in "scrub" (rain forest).

This new species is sufficiently compared with others in the key, above.

Notonomus masculinus n. sp.

With characters of doddi subgroup (above); a little broader than usual but otherwise of about average form for genus; black, faintly purplish above, greenish at middle of pronotum, appendages black to piceous; head and pronotum dull, elytral intervals more shining; reticulate microsculpture very fine and isodiametric on head and elytra, replaced by close longitudinal strigae on pronotum. Head normal, not large, .66 and .65 width prothorax in 8 우 measured. Prothorax $1 / 4$ to $1 / 3$ wider than long; base $1 / 5$ or less wider than apex; sides moderately arcuate, then straight and converging to obtuse but denticulate posterior angles; base slightly sinuate; apex broadly emarginate, with anterior angles not advanced beyond line of emargination, narrowly rounded; lateral margins very narrow; baso-lateral impressions linear; disc almost flat, impunctate, with middle line distinct but transverse impressions obsolete; base and apex not margined at middle. Elytra 
rather broad, about $1 / 5$ wider than prothorax; not much narrowed anteriorly; sides very broadly arcuate; anterior margin entire, about rectangular and at most finely dentate at humeri; striae deep, not visibly punctate; intervals convex, strongly catenulate, 3rd impunctate (in all specimens). Secondary sexual characters of $\hat{\delta}$ normal, but $i$ with anterior tarsi, though not much dilated, with first segment conspicuously biseriately squamulose below. Length about 17.5-20.5; width 5.4-6.6 mm.

Holotype of (M. C. Z. Type No. 29,013) and $4 \hat{\circ} 1$ \% paratypes all from Millaa Millaa, Atherton Tableland, North Queensland, about 2,500 ft. altitude, April, 1932. Also 2 specimens ( $\hat{o}$ o ) , not types, from Herberton, Atherton Tableland, July, 1951, collected by and received from Dr. J. G. Brooks.

This species too is sufficiently compared with others in the key, above. The carrying over into the female sex of a part of the clothing of the male front tarsus is unique among Carabidae, so far as I know. Since the squamules are conspicuously present on the first segment of both front tarsi of two females from different localities, I suppose that this is a specific character and not an individual abnormality.

\section{Notonomus triplicatus n. sp.}

With characters of doddi subgroup (above); form about average for genus; piceous, dull bronze above, appendages piceous to brown; entire upper surface rather dull, with fine, well impressed, isodiametric microsculpture. Head normal, not large, .65 and .63 width prothorax in $\hat{o}$ o measured. Prothorax $1 / 4$ to $1 / 3$ wider than long; base about $1 / 5$ or less wider than apex; sides moderately arcuate for most of length, nearly straight and converging near base; posterior angles obtuse but subdenticulate; base slightly sinuate; apex broadly emarginate, with anterior angles not advanced beyond line of curve of emargination, narrowly rounded; lateral margins narrow only slightly wider basally; baso-lateral impressions linear; disc only slightly convex, impunctate, with middle line distinct but transverse impressions indistinct; base and apex not margined at middle. Elytra moderately broad, subparallel, not 
much narrowed anteriorly, about $1 / 8$ or $1 / 7$ wider than prothorax; anterior margin entire, rectangular and subdentate at humeri; striae deep; intervals convex, subcatenate or catenate especially posteriorly, 7 th tripled, 3rd with 2 setigerous punctures, near middle of length and behind posterior $1 / 4$. Length about 18 ; width about $5.6 \mathrm{~mm}$.

Holotype \& (M. C. Z. Type No. 29,014) and 3 paratypes ( $s \circ q$ ) all from Lake Barrine (type) and the nearby town of Yungaburra, Atherton Tableland, about 2,300 ft. altitude, April, 1932.

Like the preceding ones, this new species is sufficiently compared with previously known species in the key, above. In many ways it is much like the preceding new species (masculinus), but it differs strikingly in the tripling of the seventh interval and in microsculpture, and the female has normal, unmodified front tarsi. 

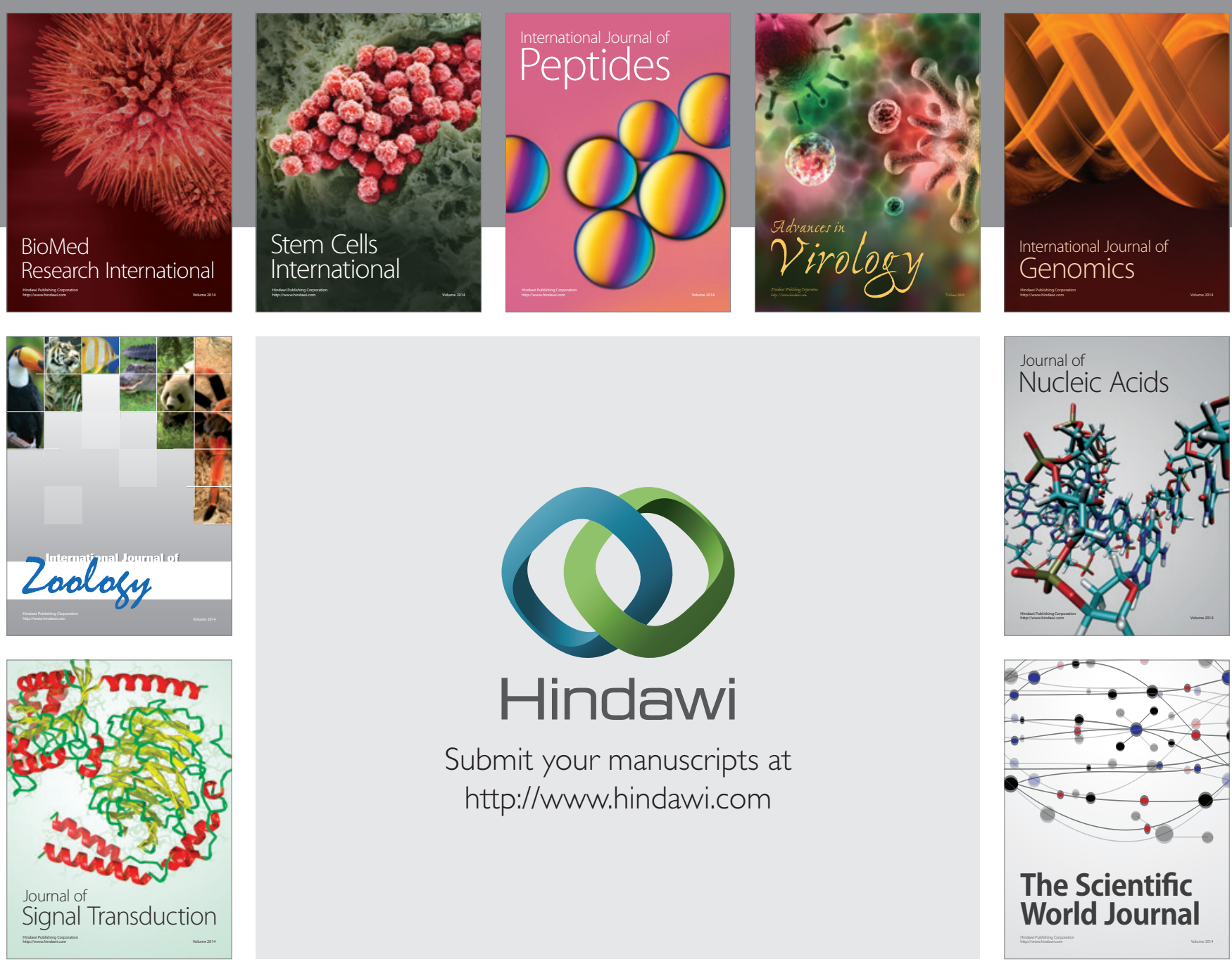

Submit your manuscripts at

http://www.hindawi.com
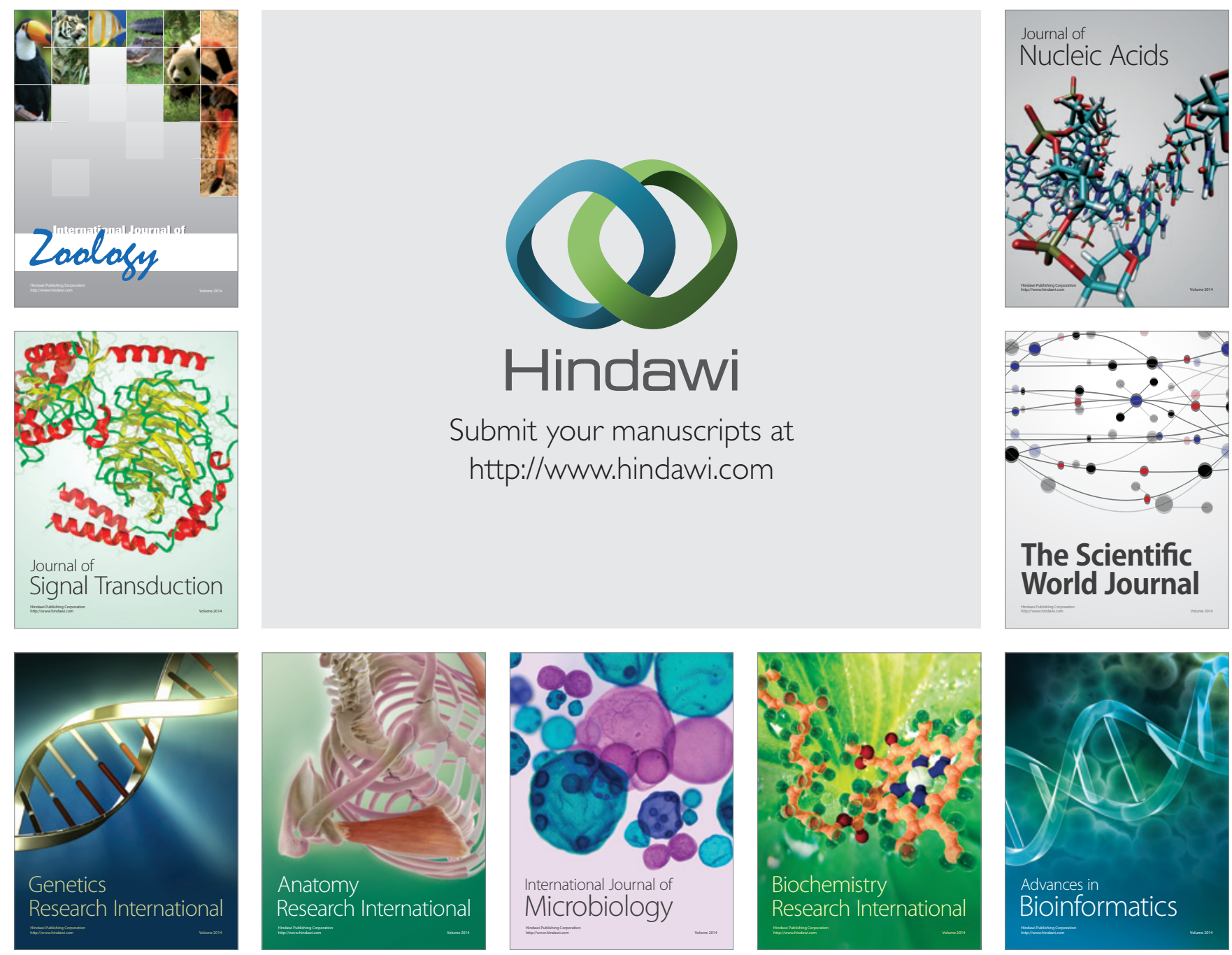

The Scientific World Journal
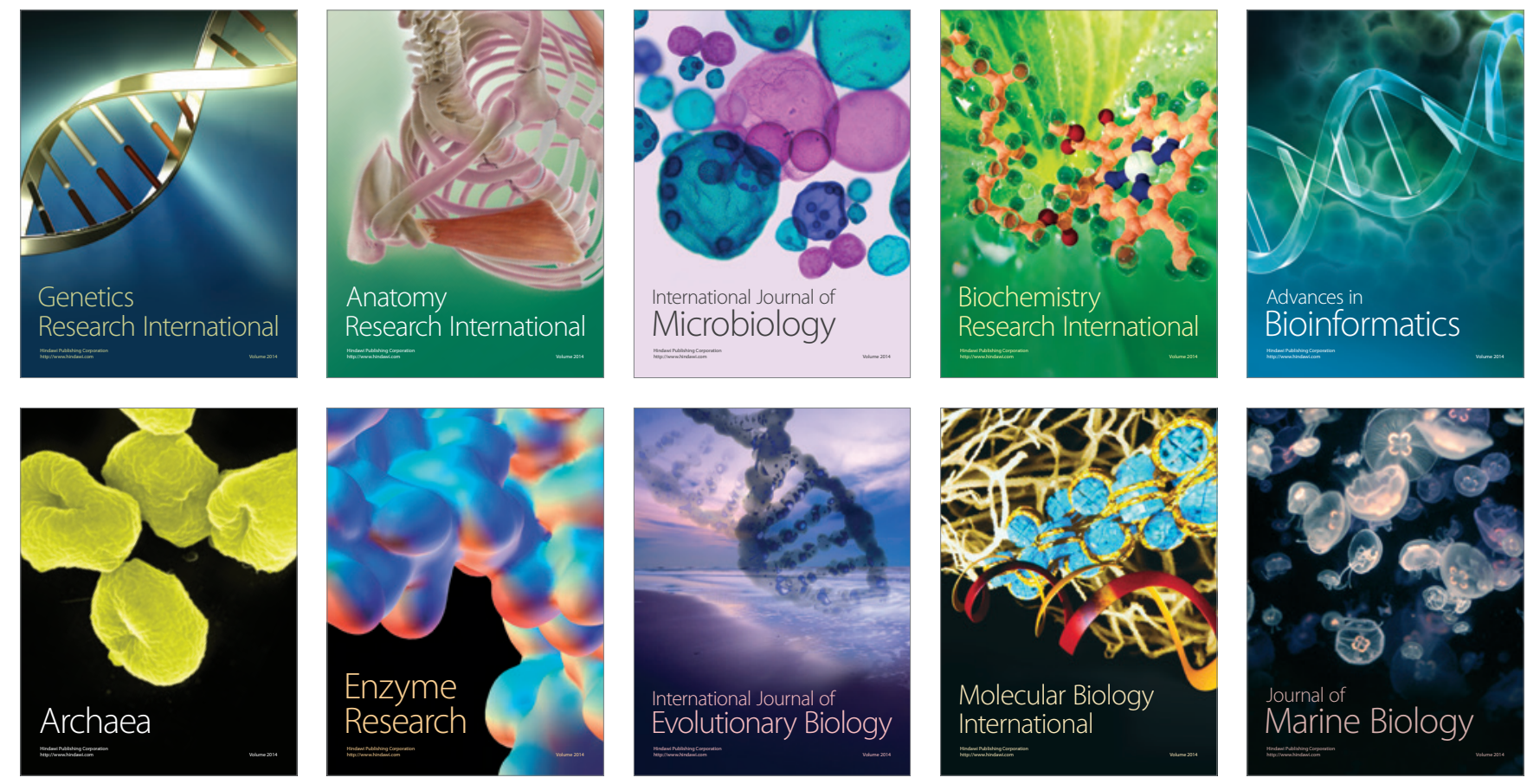